\title{
An Appraisal of Legal and Institutional Framework of Corruption Eradication in Nigeria
}

\author{
Salisu Ahmed Kabiru \\ Public Administration Department, Faculty of Social and Management Sciences Umaru \\ Musa Yar'adua University, Katsina
}

\begin{abstract}
Over the past few decades, Nigeria have had a number of laws and institutions for the eradication of corruption, but little has been achieved in the fight for corruption as the monster is fast spreading. This paper appraises the laws and institution for corruption eradication with a view to identify the factors that militate against the ineffectiveness of these laws and institutions in Nigeria. The paper utilizes a secondary source of data collection and an analytical method of data analysis. Analytical findings shows that, duplication of duties, and some lapses in some of laws were some of the factors that rendered these laws and institutions ineffective. This paper, therefore, suggest that, to make these laws and institution more effective the following measures must be taken, which include merging of some similar institutions, and rectifying lapses that characterized some of the laws.
\end{abstract}

Keywords: Appraisal, Corruption, Eradication

\section{Introduction}

For a large part of the 21th century, both developed and the developing countries around the world were perturbed with the pace at which corruption is spreading, affecting virtually all aspect of the social and economic development of such countries. Even though, a lot has been written and said in both academic and professional domains about the evils of corruption especially to the development and growth of nation, corruption continue to spread like hurricane, defying all the strategies against its spread (Okekecha,2013; Morris,2019). Consequently, a renew global fight to curtail the spread of corruption within nations and internationally is ensued, where Interpol and other International security agencies are collaboration to curtail the menace. The fight against corruption should not be limited to one country, as the effect of corruption is globally felt as 16 billion dollars which will have been used to develop infrastructural facilities in some of the countries in the world was lost to corrupt individuals (Waziri, 2009).

In Nigeria, the fight against corruption has not been a new phenomenon, it started during the colonial era and immediately after independence, where inquiries and panels were constituted to investigate allegation of corruption majorly election rigging (Joda, 2011). However, a noticeable fight against corruption was stated during General Murtala regime, where several public officials were convicted on corruption charges (Iroanusi, 2006; Ijewereme, 2015). The establishment of a formidable institution for fighting corruption was done during Shagari 
where Code of Conduct Bureau and Code of Conduct tribunal were established. In 2004, Obasanjo established Economic and Financial Crime Commission (EFCC) and was saddled with the responsibility of eradicating corruption in all its various forms (Ribadu, 2012).

Based on this backdrop, this paper examines the various institutions of fighting corruption in Nigeria with the view of appraising their strength and weakness for a possible solution to enhance their performance. The paper uses secondary source of data for the study and analytical method was utilized as the tool for data analysis.

\section{Literature Review}

The term corruption was derived from the Latin word "corruptus" meaning to destroy. The word is used in this sense to indicates the destructive nature of corruption that affect every fabric of society where it is perpetrated (Nicholls, 2006). Corruption is a complex phenomenon and various factors and forces have conspired to cause it and spread it everywhere (T I, 2011). Studies from development studies perspective has attributed the failure of certain low-income countries to develop to corruption, and there are recent empirical studies which substantiate the link between corruption and lower investment, and growth in some developing countries (Mauro 1995; World Bank 1997). Despite the volumes of studies on corruption, yet, there is scanty empirical study that establish the main causes of corruption due to contextual differences, however, from the little studies that examine the causes of corruption, moral decadence is single out to be one of the main causes of corruption (Iroanusi,2006).

Other studies on corruption such as Farrales (2005), and Wasow (2011) indicated that, greed and the desire for power as well as the wish to advance oneself in society are primary reasons for corruption. Similarly, corruption usually prosper in societies which places high value on money, power and status in life (Akpa,2018). As asserted by Joda (2011), apart from greed, the fall in education standard, poor maintenance culture, indiscipline, lack of patriotism, unhealthy competition for power and resources among politician, long military rule, civil upheaval, poor sectoral linkages, dishonesty, and mis-presentation were some of the causes of corruption in Nigeria. Relatedly, Idris (2016) traced the causes of corruption to moral decadence, the decay in moral base of most Nigerians is obviously an underpinning factor for the growth and spread of corruption in Nigeria. In the same vein, Iroan (2006) submit that, the absent of moral behavior among leaders and the followers, prone people to compromises and once you compromise your values for greedy gain, the consequences transcend beyond taking bribe, and stealing, it goes to truncating the society's growth and development. From the perspective of systemic corruption, Stanley (2010), attributes the causes of corruption to discretionary power given to politician and bureaucrat which provide them with discretion over creation and interpretation of regulation which they manipulate for their personal gain.

\section{Analysis of Financial and Legal Institutions for Eradication Corruption}

\section{The Failed Bank (Recovery of Debt and Financial Malpractice in Bank Act 1991)}

The Failed Bank (Recovery of Debt and Financial Malpractice in Bank Act was promulgated in 1991 and was amended in 1994 to recover overdue loan and stolen fund. As was empowered by the Act, the CBN revoked the licenses of 26 Banks with effect from January 16, 1998. Other power of the Act includes:

$>$ To recover the remaining outstanding as at the date the bank is closed or declared a failed bank by the Central Bank of Nigeria;

$>$ To try the offences specified in part III of this Act; 
$>$ To try the offences specified in the Banks and Other Financial Institutions Decree 1991 and the Nigeria Deposit Insurance corporation Decree 1998; and

$>$ To try other offences relating to the business or operation of a bank under any enactment.

> The Tribunal shall, exercise exclusive jurisdiction over all ancillary matters, including remand, bail and any other preliminary issues connected with an offence or hearing over which the Tribunal has jurisdiction.

\subsection{The Advance Fee fraud and Other Related Offences Act 1995}

Advance Fee Fraud and other Fraud Related Offences Decree of 1995 was originally enacted during the military regime but was repeal by an Act during the civilian rule as Act 2006 of Advance Fee Fraud and other Fraud Related Offences of the Federation of Nigeria (Okekeocha, 2013).

Offenses under the Act include:

$>$ Obtaining property by false pretense, etc

$>$ Use of premises

$>$ Fraudulent invitation.

> Receipt of fraudulent document by victim to constitute attempt.

> Possession of fraudulent document to constitute attempt.

$>$ Laundering of fund obtained through unlawful activity, etc.

$>$ Conspiracy, aiding, etc.

$>$ Conviction for alternative offences.

$>$ Offences by bodies cooperate.

Restitution.

Under this Act the court has the following jurisdiction:

Jurisdiction to try-offences, etc.

Possession of pecuniary resources not accounted for.

Power to control property of an accused person.

Power to make order of forfeiture without conviction for an offence.

Power to arrest and to grant bail.

\subsection{The Corrupt Practices and Other Related Offices Act ICPC 2000}

In order to cleanse the public sector of corruption in Nigeria, Obasanjo initiated the establishment of the Independent Corrupt Practices and Other Related Offences Commission (ICPC) in September 2000 (Salihu 2007, 10 January).

The commission was given the authority among other things to:

To receive and investigate reports of corruption

To prosecute the offender(s),

$>$ To examine, review and enforce the correction of corruption prone systems and procedures of public bodies, with a view to eliminate corruption in public life, 
$>$ To educate and enlighten the public on and against corruption, and related offences with a view to enlisting and fostering public support for the fight against corruption.

> To order or assist any officer as well as agency or parastatals on strategies through which corruption of any kind may be eradicated or reduced.

> To advise chief executives of government parastatals to make changes in practices, systems or procedures which will enhance effectiveness of the public bodies, in discharging their duties so as to block all possible loopholes where bribery, corruption, and related offences exist.

\subsection{The Money Laundering Amendment Act 2003}

Nigeria being one of the signatories to the Vienna and the Palermo convention was duty bound to initiate and implement the money laundering counter measures that was contained in the provisions of FATF. In Nigeria, the Vienna Convention was not fully initiated and implemented as was then under a military regime. Although, the military regime has subsequently ratified the instrument as contained in the convention, there was nothing tangible on anti-money laundering laws until 1995 when the Money Laundering Decree was promulgated. Due to the inadequacy of the degree, in 1995 the degree was replaced with an Act in 2003, and in order to improve the Act to meet the international standard, it was amended in 2004, and subsequently in 2011 with (Money Laundering Prohibition 2011 Act) (Nasir, 2017).

In 2016, a new bill was before the national assembly for enactment which provide for more purposeful fight against corruption and money laundering. The bill will repeal the Money Laundering (Prohibition) Act, 2011 and enact the Money Laundering Prevention and Prohibition 2016 Act which will provide for measures for the prevention and prohibition of money laundering in Nigeria and for other related matters. The new bill will provide for a single set of money laundering offences which will be applicable throughout Nigeria to the proceeds of all crimes, as well as providing a disclosure regime, which will make it an offence concealing knowledge or suspicion of money laundering (Nasir, 2017).

\section{Powers and Functions of the Authority}

> The Authority shall act as the agency responsible for receiving, analyzing, obtaining and disseminating information which relates to or may relate to the proceeds of the offences under this Act and the Proceeds of Crime Act No. 10 of 1993 or any enactment replacing it.

$>$ The authority shall collect, receive and analyze reports submitted to the authority by financial institutions and businesses of a financial nature under this Act and Proceeds of Crime Act No. 10 of 1993 and information received from any Foreign Financial Intelligence Unit.

> Enter into the premises of a financial institution or business of a financial nature during normal working hours and inspect a transaction record kept by the financial institution or business of a financial nature;

$>$ Require the production of such information that the Financial Intelligence Authority considers relevant to the fulfillment of its functions;

> Ask questions relevant to a transaction record inspected under paragraph (b);

$>$ Make notes or take a copy of part or all of the transaction record inspected under paragraph (b);

> Instruct a financial institution or business of a financial nature to take steps as may be appropriate to facilitate an investigation by the Financial Intelligence Authority. 
> Issue from time to time guidelines to financial institutions or businesses of a financial nature as to compliance with this Act and regulations made under the Act;

\subsection{Economic and Financial Crime Commission (EFCC)}

In order to curtail the sporadic spread of corruption in Nigeria, Obasanjo initiated the establishment of the anti-graft commission in 2003 which is called the Economic and Financial Crimes Commission (EFCC). The main function of the commission as a law enforcement agency was to investigate financial crimes such as Advance Fee Fraud (419 fraud) and money laundering. While ICPC focusses on corruption in the public sector, especially bribery, gratification, graft, and abuse or misuse of office, the EFCC on the other hand and as sister commission has a wider scope where the commission was given the authority to investigates people in all sectors who appear to be living above their means, and the commission is also empowered to investigate and prosecute money laundering and other financial crimes, the commission also tracks illicit wealth accruing from abuse of office, especially those who attempts to integrate such wealth into the financial system (Ribadu, 2012).

The commission was given the power among which to:

$>$ To ensure the enforcement and the due administration of the provisions of the Act.

$>$ To investigate all financial crimes including advance fee fraud, money laundering, counterfeiting, illegal charge transfers, futures market fraud, fraudulent encashment of negotiable instruments, computer credit card fraud, and contract scam,

$>$ The co-ordination and enforcement of all economic and financial crimes laws and enforcement functions conferred on any other person or authority.

$>$ The adoption of measures to identify. trace, freeze, confiscate or seize proceeds derived from terrorist activities.

> The adoption of measures which include co-ordinated preventive and regulatory actions, introduction and maintenance of investigative and control techniques on the prevention of economic and financial related crimes.

$>$ The facilitation of rapid exchange of scientific and technical information and the conduct of joint operations geared towards the eradication of economic and financial crimes.

> The examination and investigation of all reported cases of economic and Financial crimes with a view to identifying individuals, corporate bodies or groups involved.

$>$ The determination of the extent of financial loss and such other losses by government, private individuals or organizations.

> Collaborating with government bodies both within and outside Nigeria carrying on functions wholly or in part analogous with those of the Commission

\subsection{The Code of Conduct Bureau}

The Nigerian Code of Conduct Bureau was originally military imitative of General Murtala administration but was constitutionally established in 1979 by the Shagari administration. The Bureau members were selected and inaugurated on 30 July 1980. The Code of conduct bureau got its legitimacy from the 1979 constitution and its functions were clearly stated as follow:

To receive declaration of assets of public officers made pursuant to the code of conduct

To retain custody of such declaration and make them available for inspection by any citizen of Nigeria on such items and condition as the national assembly may prescribe. 
To examine the declaration and ensure that it comply with the requirement of the code of conduct bureau and of any law for the time being in force.

As from 1999 to 2007 out of the 4 million eligible public officers only 784,000 public officers returned their completed assets declaration forms (CADFs) representing $19.6 \%$ rate of compliance which indicate the low performance of the Bureau in terms of enforcing the law (Audu,2012). Similarly, out of the number of complaints received by the CCT, only 11,640 were referred to the CCT for trials, out of which only 3,304 attended to and the remaining were either adjourned until it died down or struck out for lack of merit (Audu,2012).

\subsection{Fiscal Responsibility Act 2007}

The Fiscal Responsibility Act 2007 was enacted in 2007 which paved the way for the creation of the body known as the Fiscal Management Council that will serve as a regulatory and supervisory body in the public sector (Vincent, 2007). Under the Act, a commission will be created which comprises the Fiscal Responsibility Council and the Governing Board. The Council is charged with the responsibility of monitoring and enforcing the provisions of the Act to ensure accountability, transparency and prudence in the management of the nation's resources by all tiers of government, government corporations or companies and agencies. The Fiscal Responsibility Act (2007) is a law to redirect government at all levels to imbibe a fiscal behavior that will promote prudence and sound financial management in the system as well as acting as watch dog on the activities of the public office holders and as checks on financial encroachment between and among tiers of government which is assumed to bring sanity and responsiveness into the public sector and among the various tiers of government in Nigeria (Vincent, 2007).

\section{Powers and Functions of the Commission}

$>$ To compel any person or government institution to disclose information relating to public revenues and expenditure.

> Initiate an investigation into whether any person has violated any provisions of this Act.

$>$ The Commission shall forward a report of the investigation to the Attorney General of the Federation for possible prosecution.

$>$ The Commission shall monitor and enforce the provisions of this Act and by so doing, promote the economic objectives contained in section 16 of the Constitution;

$>$ Disseminate such standard practices including international good practice that will result in greater efficiency in the allocation and management of public expenditure, revenue collection, debt control and transparency in fiscal matters.

> Undertake fiscal and financial studies, analysis and diagnosis and disseminate the result to the general public; d. Make rules for carrying out its functions under the Act; and e. Perform any other function consistent with the promotion of the

From the above analysis, it is seen that, Nigeria has a good number of institutions and anticorruption laws on the book that essential can eradicate corruption, but the reality is that, despite all these laws and institution, corruption is in the increase stagnating and derailing the Nigerian quest of being among the 20th economy in the world. The continue blossoming of corruption in Nigeria cannot be attributed to lack of laws or institutions, but lack of integrity, sincerity, honesty, patriotism, fear of God, and the lack of courage on the side of the government and its anti-graft agencies in eradicating corruption (Ribadu,2010). 
Similarly, Akpa (2018) had identified institutional framework, lack of political commitment and willingness on the part of the political leadership as factors responsible for the ineffective performance of these institutions and Acts. For example, in the past three years, more than fifteen ex- Governors, who were alleged to have embezzled public funds estimated at one hundred and seventy-two billion naira have been arrested and charged to court, but only one governor was prosecutive recently, while the rest were moving about freely. Again, on duplication of duties, the chairman of the ICPC Ayoola, has complained about overlap between ICPC, EFCC, and Transparency Monitoring Units (TMU). This kind of duplication of responsibilities tends to create tension among these institutions thereby fueling hatred which invariably demoralize those institutions in discharging their responsibilities. For instance, in September 2009, a Federal High Court judge refused a request to issue a mandamus order compelling the ICPC and the EFCC to investigate and prosecute the FCT Minister, Senator Adamu Aliero, over alleged diversion of N10.2 billion public funds while he was the governor of Kebbi State. The court explained it did not have the authority to compel the agencies to act. Furthermore, of the petitions that the ICPC received which total 942 petitions, about 400 of the petitions were under investigation, and 60 were at various stages of prosecution (Olajuwon, 2009, 25 June).

After the first 12 years of existence, the ICPC had failed to make any major convictions despite the huge number of cases, this is because as at 2015, the ICPC had a list which contained 267 criminal cases, between 2001 and 2015, and 142 civil cases between 2007 and 2015. Another lapses of the ICPC was, the excuse it gave on its inability to treat the several petition it received against state governors by claiming that, it doesn't have the power to investigate state governors, but the ICPC has the power to ensure that governors declare their asset on assumption of office and when going out of office, which the ICPC failed to do and has allowed the governors to embezzled public fund (Usman,2011; Akpa, 2018).On the money laundering Act, there are some lapses which criminal individual could exploit such as section 15 subsection 14 Bill, which listed some transactions that qualify as an arrangement, the information provided is limited to legal practitioners, it does not cover other professionals and corrupt institutions who intend laundering money through the structure may use this loophole for their money laundering (Esoimeme, 2017).

\section{Conclusion}

From the analysis as highlighted by this study, it has been established that, Nigeria has a good number of laws and institutions for fighting corruption, but despite these laws and institutions corruption has remained unabated in the society. One of the plausible reasons for the ineffectiveness of the laws and the institution in curtailing corruption was the inability to deficiency of the laws which allow individual exploit in carrying out their dubious activities. Another reason for ineffectiveness of these laws and institutions was duplication of duties which led to rivalry amongst the institutions.

\section{Remedies}

In order to strengthen the laws and institution for eradicating corruption this study suggested some ways which include:

Rebuild the moral base of Nigerians, where the culture of integrity, honesty, sincerity, hard work, love for others and dedication will be the other of the day.

Institutions and Act that are performing almost the same functions should be merge to together to avoid duplication of duties and unhealthy rivalry. 
Acts pertaining to corruption should be revisited to identify areas where there is lapses and make adjustment.

Rather than having strata of laws and anti-corruption institutions, effort need to be channel toward enforcing the existing law and powering the institutions to do their assignment without fear and favor.

\section{References}

Akpa, O. C. (2018). Neuroeconomics of Corruption: Feelings, Brain and the Nigerian Narratives (Doctoral dissertation, The Claremont Graduate University).

Audu, J. (2012). An Assessment of the Code of Conduct Bureau and Code of Conduct Tribunal (CCB and CCT)'S Public Ethics Practices (1999-2007) (Doctoral dissertation, Ahmadu Bello University, Nigeria).

Bola Olajuwon (25 June 2009). "ICPC, EFCC chiefs, others task anti-money laundering body on service. Retrieved from https://www.google.com/search?q=Bola+Olajuwon+(25+June+2009).+\%22ICPC,+EFCC+ch iefs, +others+task+antimoney+laundering+body+on+service\&tbm $=$ isch\&source $=\mathrm{hp} \& \mathrm{sa}=\mathrm{X}$ \&ved=2ahUKEwj3otnz9Y_hAhUMi3AKHXoFD6oQsAR6BAgJEAE\&biw=1370\&bih=644

EFCC (2016). Conviction of corrupt persons. Retrieved from https://efccnigeria.org/efcc/images/CONVICTIONS2016.pdf

Esoimeme, E. E. (2017). The Nigerian Money Laundering (Prevention and Prohibition) Bill, 2016: a critical appraisal. Journal of Money Laundering Control, 20(1), 79-88.

Farrales, M. (2005). What is corruption?: A history of corruption studies and the great definitions

debateshttps://scholar.google.com/scholar?hl=en\&as_sdt=0\%2C5\&q=What+is+Corruption $\% 3 \mathrm{~F} \% 3 \mathrm{~A}+\mathrm{A}+$ History+of+Corruption+Studies+and+the+Great+Definitions+Debate\&btnG= (accessed on 15 April 2019).

Idris, M. (2016). Corruption in Nigeria, causes, effect and remedies. Journal of Economic and Development, 1(4), 2-8.

Ijewereme, O. B. (2015). Anatomy of corruption in the Nigerian public sector: Theoretical perspectives and some empirical explanations. Sage Open, 5(2).

Iroanusi,S.O. (2006).Corruption: The Nigerian example. Lagos: Sam Iroanusi Publication

Joda,T.H.(2011). Anti-corruption handbook for Nigerian youths: A fundamental paradigm for rebranding education, business, politics and public administration. Zaria: Ahmadu Bello University Press.

Mauro, P. (1995). Corruption and growth. The quarterly journal of economics, 110(3), 681-712.

Morris, S. D. (2008). Disaggregating Corruption: A Comparison of Participation and Perceptions in Latin America with a Focus on Mexico 1. Bulletin of Latin American Research, 27(3), 388409.

Morris, S. D. (2019). Linking Crime and Corruption: The Case of Mexico. In Corruption in Latin America. America: Springer

Nasir, M. A. (2017). The existing legal instruments on AML/CFT in Nigeria: relevance to Islamic banking institutions. International Journal of Business, Economics and Law, 14(4). 
Nicholls,C., Daniel, T., Bacarese, A., \& Hatchard, J. (2011). Corruption and misuse of public office. England: Oxford University Press.

Nwankwo, R. N. (2013). Official corruption and poverty reduction in Nigeria: a critical assessment (2003-2010). International Journal of Arts \& Sciences, 6(2), 305.

Nwanma, Vincent (2007). Fiscal Responsibility - Don't Spend Money Unless You Have It. Retrieved from http://www. budgetmonitoring. org/Spotlights/2007/12/13/ =(accessed on 15 April 2019).

Okekeocha C. (2013). A case study of corruption and public accountability in Nigeria (Master's thesis). (Department of Political Science and International Affairs, College of Humanities and Social Sciences, Kennesaw State University)

Ribadu, H. (2012). Corruption in Nigeria. Retrieved from the/ http://www.channelstv.com/home/wp-content/uploads/2016/Report-Of-Ribadu-LedPetroleum-Revenue-Special-Task-Force-2012.

Salihu Othman Isah (10 January 2007). When EFCC and ICPC praise Shekarau. Daily Triumph. Retrieved and Accessed on 25 th February 2019.

Stanley,C.I.(2010). How Africa underdeveloped Africa. Port Hartcourt: Professional Printers and Publishers.

Transparency International (2011). Corruption perceptions Index, Berlin: TI.

Usman, S. (2011). The opacity and conduit of corruption in the Nigeria oil sector: Beyond the rhetoric of the anti-corruption crusade. Journal of Sustainable Development in Africa, 13(2), 294.

Vincent, N. (2007). Fiscal Responsibility - Don't Spend Money Unless You Have It. http://www. budgetmonitoring. org/Spotlights/2007/12/13/=(accessed on 15 April 2019).

Wasow, B. (2011). What trends in the prevalence of corruption has the world experienced in recent years? Retrieved from https://www.theglobalist.com/a-very-brief-history-ofcorruption/ (=(accessed on 15 April 2019).

Waziri,F.(2009). How to fight corruption. Retrieved from https://efccnigeria.org/efcc/publicnotices=(accessed on 15 April 2019).

World Bank (2017). Corruption around the globe. The World Bank, Washington DC. 